\title{
The effect of weaning diet on the subsequent colonic metabolism of dietary fibre in the adult rat
}

\author{
BY ELIZABETH F. ARMSTRONG, MARTIN A. EASTWOOD, \\ CHRISTINE A. EDWARDS AND W. GORDON BRYDON \\ Gastrointestinal Laboratories, Department of Medicine, Western General Hospital, \\ Edinburgh EH4 $2 X U$ \\ AND CECILIA C. A. MACINTYRE \\ Medical Statistics Unit, Faculty of Medicine, University of Edinburgh, Edinburgh
}

(Received 9 April 1991-Accepted 7 January 1992)

\begin{abstract}
The effect of the weaning diet on the subsequent colonic metabolism of bran and pectin in the adult rat has been investigated. Feeding a fibre-reduced diet on its own or supplemented with bran (WB) and pectin (P) from weaning (fibre-reduced (weaning)) was compared with introducing the same diet to age-matched rats reared on a standard laboratory diet from weaning (fibre-reduced (6 weeks)). The effects of the diets on colonic metabolism were measured by wet and dry caecal contents and stool weights, caecal sac weight, and caecal and faecal short-chain fatty acids (SCFA). Final body-weights were greater for fibrereduced (6 weeks) and fibre-reduced (6 weeks) + P groups, but not fibre-reduced (6 weeks) + WB, than those of the fibre-reduced (weaning) rats. Rats fed on fibre-reduced (6 weeks) diet had a higher total caecal SCF A content than fibre-reduced (weaning) control rats. Fibre-reduced (weaning) + P-fed rats had a threefold higher caecal concentration of both propionate and butyrate than the matched fibre-reduced (6 weeks) $+P$ group. Fibre-reduced (weaning) + WB animals had a significantly higher butyrate caecal concentration compared with their matched fibre-reduced (6 weeks) + WB group. Fibre-reduced (weaning) + P-fed rats had a lower faecal output than the fibre-reduced ( 6 weeks) + P rats. There was no difference in faecal output in rats fed on either fibre-reduced (6 weeks) + WB or fibre-reduced (weaning) + WB. The faecal concentration of SCFA was in general higher in the rats fed on fibre-reduced (weaning) alone, $+P$, or + WB than in those fed on fibre-reduced ( 6 weeks) alone, $+P$ or + WB. Faecal output of total and individual SCFA was increased on the fibre-reduced (weaned) + WB diet compared with fibre-reduced ( 6 weeks) + WB-fed animals. The diet at weaning may be important in determining the pathways of caecal bacterial metabolism in the adult rat. In studying the effect of a dietary fibre on caecal metabolism and faecal output, when the diet is changed appears to be important.
\end{abstract}

Weaning diet: Colonic metabolism: Pectin: Wheat bran

The importance of the colonic fermentation of complex carbohydrates in health and disease has become very evident in the last two decades. The extent and nature of the fermentation will determine the influence of the carbohydrate on stool output (McBurney et al. 1985), cholesterol homeostasis (Chen \& Anderson, 1984), and colonic nutrition (Roediger, 1982). The inaccessibility of the caecum and proximal colon, the major sites of fermentation, makes direct investigation of colonic fermentation in man very difficult and much work relies on the use of animal models. The use of animals also allows for better dietary control and longer test-diet periods.

In the majority of experiments where caecal metabolism and nutrition are investigated, animals are initially weaned onto a standard laboratory diet before transfer onto the test diet (Illman et al. 1982; Demigne \& Remesy, 1985; Walter et al. 1986). It is probable, 
Table 1. Composition of basic diets fed to rats

\begin{tabular}{|c|c|c|}
\hline $\begin{array}{l}\text { Dietary constituent } \\
(\mathrm{g} / \mathrm{kg})\end{array}$ & $\begin{array}{l}\text { CRMX* }^{*} \\
\text { diet }\end{array}$ & $\begin{array}{l}\text { Fibre-reduced } \\
\text { diet }\end{array}$ \\
\hline $\begin{array}{l}\text { Crude protein (nitrogen } \\
\times 6.25 \text { ) } \dagger\end{array}$ & 183 & 148 \\
\hline Crude fat $t$ & 29 & 25 \\
\hline Carbohydrate & 563 & 680 \\
\hline Starch analysis & 492 & - \\
\hline Resistant starch $\ddagger$ & nd & - \\
\hline Dietary NSP\& & 133 & 45 \\
\hline Soluble & 31 & 14 \\
\hline Insoluble & 102 & 31 \\
\hline
\end{tabular}

NSP, non-starch polysaccharides.

* Stock diet; Labsure, Croydon.

$\dagger$ Protein and fat analysis results were provided by Special Diet Services, Witham, Essex.

Determined by Siljestrom \& Asp (1985).

$\$$ Determined by the Englyst et al. (1982) method.

however, that the diet at weaning has some influence on the establishment of the bacterial flora within the colon. The sparse initial flora of the neonate (strongly influenced by the mother; Savage, 1977) may be modified by the diet at weaning. Subsequent changes may be more difficult to achieve as the bacterial populations become more established and numerically larger. Changes in caecal metabolism induced by altered diet in animals with an established caecal flora are unlikely to stabilize in less than 4 weeks (Walter et al. 1986). Carry-over effects from previous diets have been noted in studies of the action of wheat bran (WB) in humans and may influence rat experiments in a similar manner (Eastwood et al. 1973).

In the present study the effect of the diet at weaning on the subsequent metabolism of three diets containing different amounts and types of dietary fibre has been investigated. Feeding a fibre-reduced diet on its own or supplemented with WB and pectin (P) from weaning ( $12 \mathrm{~d}$ ) was compared with introducing the same diet from 6 weeks to age-matched rats reared on a standard laboratory diet from weaning.

\section{MATERIALS AND METHODS}

\section{Animals}

Albino Wistar rats were bred in the Animal Unit, Western General Hospital, Edinburgh. Food and water were provided ad lib. Male rats (6 weeks old) which had been maintained previously on a stock diet, CRMX (Labsure, Croydon), were divided into three groups of five and fed on test diets for 4 weeks (fibre-reduced (6 weeks)). For the weaning experiment, three groups of both mothers and litters were fed on one of three test diets from day 12 after parturition to avoid the young prematurely eating the mothers' original diet. At weaning ( $21 \mathrm{~d}$ old), the male young were selected, allocated to three groups of five and continued on the same diets for 7 weeks (fibre-reduced (weaning)). Both groups of rats were 10 weeks old at the end of the experiment.

\section{Diet}

The test diets were fibre-reduced and fibre-reduced supplemented with $100 \mathrm{~g} \mathrm{WB} / \mathrm{kg}$ (fibrereduced $+\mathrm{WB}$ ) or $100 \mathrm{~g} \mathrm{P} / \mathrm{kg}$ (fibre-reduced $+\mathrm{P}$ ). The fibre-reduced diet (Special Diet Services, Witham, Essex) consisted of $(\mathrm{g} / \mathrm{kg})$ soya-bean concentrate 200, soya-bean oil 30 , 
maize flour 720, nutritionally complete vitamin and mineral premix 50. The non-starch polysaccharide (NSP) content was $45 \mathrm{~g} / \mathrm{kg}$ dry weight. High methoxylated pectin-USP was derived from citrus peel ( $\mathrm{H}$. P. Bulmer Ltd, Hereford; $964 \mathrm{~g} / \mathrm{kg}$ ). Wheat bran was a coarse Canadian Red Spring variety (95\% passed through sieve apertures $1.5-0.5 \mathrm{~mm}$; Chancelot Mills, Edinburgh). The total NSP of wheat bran was $463 \mathrm{~g} / \mathrm{kg}$. The stock diet CRMX was an expanded form of pellet diet formulated for small animals by Labsure, Croydon. The total NSP was $133 \mathrm{~g} / \mathrm{kg}$ (31 g soluble NSP, $102 \mathrm{~g}$ insoluble NSP) and contained $26 \mathrm{~g}$ cellulose (Englyst et al. 1982). Composition of the test diets is shown in Table 1.

\section{Sample collection and analysis}

Individual body-weights were recorded at the beginning of the experiment, and thereafter at the same time each week. Assessment of daily food intake was determined from left-over food and calculated on a dry-weight basis.

Rats were transferred to individual gridded cages $7 \mathrm{~d}$ before the end of the experiment. Total faecal output of each animal was collected during the three final consecutive $24 \mathrm{~h}$ periods, weighed and stored at $-20^{\circ}$.

Animals were anaesthetized with diethyl ether and killed by cervical dislocation. The caecum was isolated at the ileo-caecal valve and the beginning of the transverse colon, dissected out, and the caecal contents were removed, weighed and stored at $-20^{\circ}$.

The empty caecal sac was washed out with $9 \mathrm{~g}$ sodium chloride/1, blotted dry with filter paper and weighed. The sac weight was expressed as $\mathrm{g} / \mathrm{kg}$ body-weight to allow for the differences in final body-weight in each of the groups.

Samples were adjusted to $\mathrm{pH} 9 \cdot 0$, frozen at $-20^{\circ}$ and freeze dried. Short-chain fatty acids (SCFA) were measured per $g$ dry weight in caecal and faecal samples using the method of Spiller et al. (1980).

\section{Statistical analysis}

There was evidence of positive skewness in the data and so the data were log transformed for analysis. The consequences of this are that the differences between groups are expressed as percentages rather than absolute differences.

The levels of outcome in the two groups of rats on the basal diets were compared using a two-sample $t$ test.

The level of outcome on each experimental diet was compared with the basal diet and expressed as a percentage. The percentages were compared between the two groups separately using a test of interaction in an analysis of variance. The overall groups fibrereduced (weaning), unsupplemented or supplemented were compared with the overall group fibre-reduced ( 6 weeks) unsupplemented group to examine the overall influence of diet fibre-reduced (weaning) as opposed to diet fibre-reduced (6 weeks) in Table 7. The individual effects of supplementation with pectin (P) or wheat bran (WB) were examined in Table 8.

\section{RESULTS}

Body-weight

Fibre-reduced (weaning) and fibre-reduced (weaning) + P-fed rats had significantly lower body-weights at the end of the experiment than the rats fed on fibre-reduced ( 6 weeks) and fibre-reduced ( 6 weeks) $+P$ diets. There was no significant difference in weight between the two WB-fed groups (Table 2). The food intake over $28 \mathrm{~d}$ in the three groups was $678 \mathrm{~g}$ for the fibre-reduced groups, $698 \mathrm{~g}$ for the reduced-fibre $+\mathrm{WB}$ group and $604 \mathrm{~g}$ for the reduced-fibre $+\mathrm{P}$ group. The food conversion efficiency ( $\mathrm{g}$ weight gain $/ \mathrm{g}$ food consumed) for the respective groups was $0 \cdot 23,0 \cdot 20$ and 0.17 respectively. 


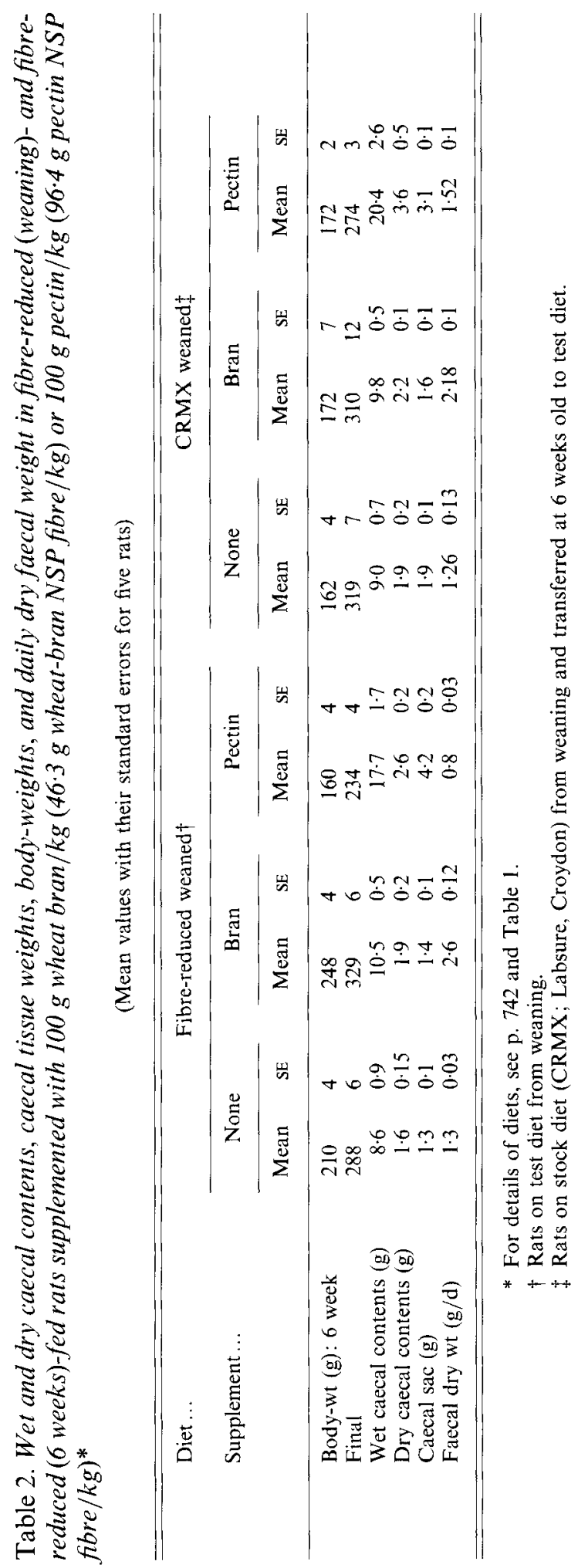


Table 3. Concentrations and total levels of short-chain fatty acids (SCFA) in dry caecal material in fibre-reduced (weaning)- and fibre-reduced (6 weeks)-fed rats supplemented with $100 \mathrm{~g}$ wheat bran $/ \mathrm{kg}(46.3 \mathrm{~g}$ wheat-bran NSP fibre $/ \mathrm{kg})$ or $100 \mathrm{~g}$ pectin $/ \mathrm{kg}(96.4 \mathrm{~g}$ pectin NSP fibre $/ \mathrm{kg})^{*}$

(Mean values with their standard errors for five rats except fibre-reduced weaned + wheat bran where six rats were used)

\begin{tabular}{|c|c|c|c|c|c|c|c|c|c|c|c|c|}
\hline \multirow{3}{*}{$\begin{array}{l}\text { Diet... } \\
\text { Supplement... }\end{array}$} & \multicolumn{6}{|c|}{ Fibre-reduced weaned $\dagger$} & \multicolumn{6}{|c|}{ CRMX weaned $\ddagger$} \\
\hline & \multicolumn{2}{|c|}{ None } & \multicolumn{2}{|c|}{ Bran } & \multicolumn{2}{|c|}{ Pectin } & \multicolumn{2}{|c|}{ None } & \multicolumn{2}{|c|}{ Bran } & \multicolumn{2}{|c|}{ Pectin } \\
\hline & Mean & SE & Mean & SE & Mean & $\mathrm{SE}$ & Mean & $\mathrm{SE}$ & Mean & SE & Mean & SE \\
\hline \multicolumn{13}{|l|}{$\begin{array}{l}\text { Concentration } \\
(\mu \mathrm{mol} / \mathrm{g})\end{array}$} \\
\hline Acetate & 284 & 26 & 297 & 6 & 430 & 34 & 499 & 41 & 323 & 17 & 368 & 41 \\
\hline Propionate & 82 & 5 & 83 & 9 & 151 & 12 & 121 & 7 & 82 & 14 & 58 & 6 \\
\hline Butyrate & 103 & 18 & 137 & 4 & 122 & 20 & 133 & 26 & 88 & 10 & 40 & 5 \\
\hline SCFA & 474 & 41 & 520 & 12 & 704 & 57 & 769 & 55 & 511 & 33 & 487 & 51 \\
\hline $\begin{array}{l}\text { Total SCFA } \\
(\mu \mathrm{mol})\end{array}$ & 220 & 37 & 330 & 43 & 441 & 58 & 464 & 63 & 347 & 14 & 489 & 89 \\
\hline
\end{tabular}

* For details of diets, see p. 742 and Table 1.

$\dagger$ Rats on test diet from weaning.

\$ Rats on stock diet (CRMX; Labsure, Croydon) from weaning and transferred at 6 weeks old to test diet.

\section{Caecal contents}

The diet at weaning, whether fibre-reduced (weaning) or fibre-reduced (6 weeks), had no effect overall (Table 7), or on the subsequent action of any supplement (Table 8) on caecal content weight, wet or dry. P-fed rats had the highest amount of wet and dry caecal contents in both diet groups (Table 2).

\section{Caecal sac weight}

Fibre-reduced (weaning)-fed animals had lower caecal sac weights than fibre-reduced (6 weeks) animals (Table 7). Both groups of P-fed rats had high caecal sac weights with fibrereduced (weaning) + P-fed rats having higher sac weights than the fibre-reduced $(6$ weeks) $+P$ group (Table 2). There was a difference in caecal sac weight between fibrereduced (weaning) + WB and fibre-reduced ( 6 weeks $)+$ WB, which included a decrease in the fibre-reduced (6 weeks) +WB group (Table 8 ).

\section{Faecal weight}

There was no difference between fibre-reduced (weaning) and fibre-reduced ( 6 weeks)-fed rats (Table 7). Fibre-reduced (6 weeks) + P-fed rats had a significantly larger stool weight compared with fibre-reduced (weaning) + P-fed rats (Table 8 ).

\section{Total amount of caecal SCFA}

The total amount of SCFA in the caecum was significantly lower in the fibre-reduced (weaning) rats compared with the fibre-reduced (6 weeks) rats (Table 7). There was a bigger increase in total SCFA (g/caecum; Table 3 ) above the respective fibre-reduced (weaning) rats in the fibre-reduced (weaning) $+\mathrm{P}$ group compared with the fibre-reduced ( 6 weeks) $+\mathrm{P}$ group $(36 v .0 \% ; P=0.06)$. The same was also true with fibre-reduced (weaning) $+\mathrm{WB}$ and fibre-reduced (6 weeks) $+\mathrm{WB}$ rats $(20 v .-11 \% ; P=0.02$; Table 8$)$. 


\section{Caecal SCFA concentrations}

Fibre-reduced (weaning)-fed rats had significantly lower acetate, propionate and total SCFA than fibre-reduced (6 weeks) rats (Table 7). Fibre-reduced (weaning) + P-fed rats had significantly higher acetate, propionate, butyrate and total SCFA than the fibre-reduced $(6$ weeks) + P-fed rats (Table 3 ). Fibre-reduced (weaning) + WB rats were significantly reduced yet still had significantly higher acetate, propionate and butyrate and total SCFA compared with their corresponding fibre-reduced (6 weeks) + WB group (Table 8).

\section{Caecal molar proportions of SCFA}

Fibre-reduced (weaning) $+\mathrm{P}$ rats had significantly more propionate and butyrate and less acetate than the fibre-reduced ( 6 weeks) $+P$ rats, and fibre-reduced (weaning) $+W B$ rats had significantly more butyrate and less acetate than the fibre-reduced ( 6 weeks) + WB rats (Table 4).

\section{Faecal SCFA}

Rats fed on fibre-reduced (weaning) had a higher faecal output of propionic acid in the stool than fibre-reduced (6 weeks)-fed rats (Table 5). There was a higher concentration of total SCFA, butyrate and propionate in the faeces of fibre-reduced (weaning) compared with fibre-reduced ( 6 weeks) rats (Table 7). However, supplementing the diet with P or WB had no effect on the concentration of SCFA with either fibre-reduced (weaning) or fibrereduced ( 6 weeks) regimen except for propionate (fibre-reduced (6 weeks) $+\mathrm{P}$ compared with fibre reduced (weaning) $+\mathrm{P} ; 19$ v. $85 \% ; P=0.02$; Table 8 ).

Table 6 shows the molar proportions of SCFA in the faecal material.

\section{DISCUSSION}

The fermentation of complex carbohydrates by colonic bacteria may determine their action on stool output and colonic function. Because of the difficulties of long-term dietary studies under controlled diet conditions in man, investigations often involve the use of laboratory animals such as the rat. There are many different experimental designs in use. The age of the rats, the feeding period of the test diet and the diet at weaning vary considerably between different studies (Demigne \& Remesy, 1985; Nyman \& Asp, 1985; Walter et al. 1986). Animals are usually weaned onto a standard laboratory rat diet and then transferred onto the test diet at a later stage in their development for a period varying from $9 \mathrm{~d}$ (Nyman \& Asp, 1985) to 4 weeks (Walters et al. 1986). These may be appropriate models to study the effect of a change in diet on caecal metabolism in adult or adolescent populations, but are probably inappropriate for the investigation of the direct influence of a complex carbohydrate on colonic function. The results of the present study have demonstrated profound differences in the caecal metabolism and stool output of rats weaned onto a test diet compared with rats transferred onto the test diet after weaning on CRMX.

In the present study three test diets were used to investigate the effect of weaning diet. Animals were either weaned directly onto these test diets or transferred as adults after previous weaning onto CRMX. The CRMX diet contained $133 \mathrm{~g}$ dietary fibre $/ \mathrm{kg}$ made up of a mixture of soluble and insoluble fibres $(1: 3.3 \mathrm{w} / \mathrm{w})$. The fibre-reduced diet (fibre reduced (weaning)) contained $45 \mathrm{~g}$ dietary fibre $/ \mathrm{kg}$ (soluble:insoluble $1: 2 \cdot 2$ ) which was fed alone or supplemented with $100 \mathrm{~g} \mathrm{WB}$ or $\mathrm{P} / \mathrm{kg}$. The aim of the present study was to evaluate the differences in caecal metabolism and stool output that may occur when an animal is transferred from a high mixed-fibre diet, typical of those used to maintain experimental rats before dietary studies, to one containing very low levels of mixed fibre, supplemented with soluble fibre or insoluble fibre in comparison with animals fed on these same diets directly at weaning. 
Table 4. Molar proportions of short-chain fatty acids (SCFA; mmol SCFA/(mol total $S C F A / 1)$ ) in dry caecal material in fibre-reduced (weaning)- and fibre-reduced (6 weeks)-fed rats supplemented with $100 \mathrm{~g}$ wheat bran $/ \mathrm{kg}$ (46.3 $\mathrm{g}$ wheat-bran NSP fibre/ $\mathrm{kg}$ ) or $100 \mathrm{~g}$ pectin $/ \mathrm{kg}(96.4 \mathrm{~g} \text { pectin NSP fibre } / \mathrm{kg})^{*}$

(Mean values with their standard errors for five rats except fibre-reduced weaned + wheat bran where six rats were used)

\begin{tabular}{|c|c|c|c|c|c|c|c|c|c|c|c|c|}
\hline \multirow{3}{*}{$\begin{array}{l}\text { Diet... } \\
\text { Supplement ... }\end{array}$} & \multicolumn{6}{|c|}{ Fibre-reduced weaned $\dagger$} & \multicolumn{6}{|c|}{ CRMX weaned $\ddagger$} \\
\hline & \multicolumn{2}{|c|}{ None } & \multicolumn{2}{|c|}{ Bran } & \multicolumn{2}{|c|}{ Pectin } & \multicolumn{2}{|c|}{ None } & \multicolumn{2}{|c|}{ Bran } & \multicolumn{2}{|c|}{ Pectin } \\
\hline & Mean & $\mathrm{SE}$ & Mean & $\mathrm{SE}$ & Mean & SE & Mean & $\mathrm{SE}$ & Mean & $\mathrm{SE}$ & Mean & SE \\
\hline Acetate & 600 & 23 & 571 & 6 & 613 & 19 & 649 & 31 & 636 & 24 & 750 & 21 \\
\hline Propionate & 176 & 9 & 159 & 14 & 215 & 6 & 158 & 10 & 156 & 18 & 120 & 11 \\
\hline Butyrate & 214 & 27 & 263 & 11 & 171 & 20 & 172 & 27 & 171 & 16 & 82 & 16 \\
\hline
\end{tabular}

* For details of diets, see p. 742 and Table 1.

$\uparrow$ Rats on test diet from weaning.

\$ Rats on stock diet (CRMX; Labsure, Croydon) from weaning and transferred at 6 weeks old to test diet.

Table 5. Concentration of individual short-chain fatty acids (SCFA; $\mu \mathrm{mol} / \mathrm{g})$, and total SCFA ( $\mu \mathrm{mol} / d$ ) in dry faecal material in fibre-reduced (weaning)- and fibre-reduced (6 weeks)-fed rats supplemented with $100 \mathrm{~g}$ wheat bran $/ \mathrm{kg}(46.3 \mathrm{~g}$ wheat-bran $\mathrm{NSP}$ fibre $/ \mathrm{kg})$ or $100 \mathrm{~g}$ pectin $/ \mathrm{kg}(96.4 \mathrm{~g} \text { pectin NSP fibre } / \mathrm{kg})^{*}$

(Mean values with their standard errors for five rats except fibre-reduced weaned + wheat bran where six rats were used)

\begin{tabular}{|c|c|c|c|c|c|c|c|c|c|c|c|c|}
\hline \multirow{3}{*}{$\begin{array}{l}\text { Diet... } \\
\text { Supplement... }\end{array}$} & \multicolumn{6}{|c|}{ Fibre-reduced weaned $\dagger$} & \multicolumn{6}{|c|}{ CRMX weaned +} \\
\hline & \multicolumn{2}{|c|}{ None } & \multicolumn{2}{|c|}{ Bran } & \multicolumn{2}{|c|}{ Pectin } & \multicolumn{2}{|c|}{ None } & \multicolumn{2}{|c|}{ Bran } & \multicolumn{2}{|c|}{ Pectin } \\
\hline & Mean & SE & Mean & $\mathrm{SE}$ & Mean & SE & Mean & $\mathrm{SE}$ & Mean & $\mathrm{SE}$ & Mean & $\mathrm{SE}$ \\
\hline \multicolumn{13}{|l|}{$\begin{array}{l}\text { Concentration } \\
(\mu \mathrm{mol} / \mathrm{g})\end{array}$} \\
\hline Acetate & 109 & 27 & 150 & 22 & 206 & 28 & 59 & 2 & 70 & 5 & 118 & 18 \\
\hline Propionate & 35 & 8 & 47 & 6 & 75 & 9 & 6 & 1 & 13 & 2 & 23 & 4 \\
\hline Butyrate & 30 & 9 & 44 & 3 & 61 & 8 & 7 & 2 & 11 & 3 & 11 & 1 \\
\hline SCFA & 174 & 42 & 240 & 31 & 342 & 41 & 76 & 2 & 94 & 9 & 152 & 23 \\
\hline $\begin{array}{c}\text { Total SCFA } \\
(\mu \mathrm{mol} / \mathrm{d})\end{array}$ & 226 & 57 & 625 & 90 & 285 & 30 & 102 & 9 & 205 & 18 & 233 & 17 \\
\hline
\end{tabular}

* For details of diets, see p. 742 and Table 1.

$\dagger$ Rats on test diet from weaning.

+ Rats on stock diet (CRMX; Labsure, Croydon) from weaning and transferred at 6 weeks old to test diet.

Several differences in caecal contents were observed between fibre-reduced ( 6 weeks) rats and fibre-reduced (weaning) rats. These differences reflected the change in amount or the type of dietary fibre in the weaning diet and the adult diet fibre-reduced ( 6 weeks). Animals had a large reduction in fibre intake from 133 to $45 \mathrm{~g} / \mathrm{kg}$. The corresponding fibre-reduced (weaning) animals had smaller caecal sac weights and less caecal fermentation after feeding for 3 weeks. Thus, an initial high-fibre diet appears to increase the capacity for caecal fermentation as shown by caecal SCFA in later life, even when the dietary fibre intake is reduced. Fibre-reduced ( 6 weeks $)+P$ and fibre-reduced (weaning) $+\mathrm{P}$ showed all the 
Table 6. Molar proportions of short-chain fatty acids (SCFA; mmol SCFA/mol total SCFA) in dry faecal material in fibre-reduced (weaning)- and fibre-reduced (6 weeks)-fed rats supplemented with $100 \mathrm{~g}$ wheat bran $/ \mathrm{kg}(46.3 \mathrm{~g}$ wheat-bran NSP fibre $/ \mathrm{kg})$ or $100 \mathrm{~g}$ pectin $/ \mathrm{kg}$ $(96.4 \mathrm{~g} \text { pectin NSP fibre } / \mathrm{kg})^{*}$

(Mean values with their standard errors for five rats except fibre-reduced weaned + wheat bran where six rats were used)

\begin{tabular}{|c|c|c|c|c|c|c|c|c|c|c|c|c|}
\hline \multirow{3}{*}{$\begin{array}{l}\text { Diet... } \\
\text { Supplement... }\end{array}$} & \multicolumn{6}{|c|}{ Fibre-reduced weaned $\uparrow$} & \multicolumn{6}{|c|}{ CRMX weaned +} \\
\hline & \multicolumn{2}{|c|}{ None } & \multicolumn{2}{|c|}{ Bran } & \multicolumn{2}{|c|}{ Pectin } & \multicolumn{2}{|c|}{ None } & \multicolumn{2}{|c|}{ Bran } & \multicolumn{2}{|c|}{ Pectin } \\
\hline & Mean & $\mathrm{SE}$ & Mean & $\mathrm{SE}$ & Mean & SE & Mean & $\mathrm{SE}$ & Mean & $\mathrm{SE}$ & Mean & $\mathrm{SE}$ \\
\hline Acetate & 624 & 39 & 618 & 16 & 601 & 14 & 781 & 33 & 745 & 26 & 775 & 11 \\
\hline Propionate & 205 & 10 & 193 & 7 & 221 & 16 & 85 & 10 & 140 & 9 & 150 & 7 \\
\hline Butyrate & 171 & 32 & 189 & 13 & 178 & 11 & 100 & 24 & 115 & 18 & 74 & 8 \\
\hline
\end{tabular}

* For details of diets, see p. 742 and Table 1.

$\uparrow$ Rats on test diet from weaning.

\$ Rats on stock diet (CRMX; Labsure, Croydon) from weaning and transferred at 6 weeks old to test diet.

Table 7. Comparison of all rats changed onto the fibre-reduced diet ( 6 weeks) with all rats weaned onto the fibre-reduced diet regardless of supplementation*

\begin{tabular}{|c|c|c|}
\hline & $\begin{array}{l}\text { Difference between fibre-reduced } \\
\qquad(6 \text { weeks) (all diets) } \\
\text { and fibre-reduced (weaned) }(\%)\end{array}$ & $\begin{array}{c}\text { Statistical significance } \\
\text { of difference: } P=\end{array}$ \\
\hline \multicolumn{3}{|l|}{ Caecal content } \\
\hline Wet & 7 & $0 \cdot 36$ \\
\hline Dry & 13 & $0 \cdot 12$ \\
\hline Caecal sac wt & 22 & 0.002 \\
\hline \multicolumn{3}{|c|}{ Caecal SCFA: Total amount } \\
\hline Acetic & 44 & $0 \cdot 003$ \\
\hline Propionic & 33 & 0.01 \\
\hline Butyric & 25 & $0 \cdot 20$ \\
\hline Total SCFA & 40 & 0.006 \\
\hline \multicolumn{3}{|c|}{ Concentration } \\
\hline Acetic & 28 & $0 \cdot 003$ \\
\hline Propionic & 18 & 0.002 \\
\hline Butyric & 11 & 0.43 \\
\hline Total SCFA & 24 & $0 \cdot 004$ \\
\hline Faecal dry wt & -3 & 0.58 \\
\hline \multicolumn{3}{|c|}{ Faecal SCFA: Total amount } \\
\hline Acetic & -18 & $0 \cdot 22$ \\
\hline Propionic & -51 & $0 \cdot 001$ \\
\hline Butyric & -44 & $0 \cdot 03$ \\
\hline Total SCFA & -26 & 0.06 \\
\hline \multicolumn{3}{|c|}{ Concentration } \\
\hline Acetic & -19 & $0 \cdot 17$ \\
\hline Propionic & -51 & $0 \cdot 001$ \\
\hline Butyric & -45 & 0.03 \\
\hline Total SCFA & -26 & 0.05 \\
\hline
\end{tabular}

SCFA, short-chain fatty acids.

* For details of diets, see p. 742 and Table 1. 
Table 8. Comparison of rats changed onto the fibre-reduced diet ( 6 weeks) with rats weaned onto fibre-reduced diet examining supplementation by wheat bran and pectin*

\begin{tabular}{|c|c|c|c|c|c|c|}
\hline & \multicolumn{6}{|c|}{ Differences from unsupplemented diet $(\%)$} \\
\hline & \multicolumn{3}{|c|}{ Pectin diet } & \multicolumn{3}{|c|}{ Bran diet } \\
\hline & Weaned & 6 weeks & $\begin{array}{c}\text { Statistical } \\
\text { significance } \\
\text { of difference: } \\
P=\end{array}$ & Weaned & 6 weeks & $\begin{array}{c}\text { Statistical } \\
\text { significance } \\
\text { of difference } \\
P=\end{array}$ \\
\hline \multicolumn{7}{|l|}{ Caecal content } \\
\hline Wet & 25 & 32 & 0.61 & 16 & 3 & $0 \cdot 12$ \\
\hline Dry & 15 & 22 & 0.51 & 15 & 6 & $0 \cdot 41$ \\
\hline Caecal sac wt & 52 & 17 & 0.001 & 10 & -9 & 0.002 \\
\hline \multicolumn{7}{|c|}{ Caecal SCFA: Total amount } \\
\hline Acetic & 38 & 7 & $0 \cdot 12$ & 18 & -12 & 0.02 \\
\hline Propionic & 49 & -12 & 0.002 & 14 & -13 & $0 \cdot 10$ \\
\hline Butyric & 24 & -26 & $0 \cdot 03$ & 33 & -9 & 0.04 \\
\hline Total SCFA & 36 & 0 & 0.06 & 20 & -11 & 0.02 \\
\hline \multicolumn{7}{|c|}{ Concentration } \\
\hline Acetic & 20 & -13 & 0.002 & 3 & -17 & 0.002 \\
\hline Propionic & 30 & -28 & 0.0001 & 0 & -17 & 0.07 \\
\hline Butyric & 8 & -40 & 0.002 & 16 & -14 & 0.03 \\
\hline Total SCFA & 19 & -18 & $0 \cdot 0004$ & 5 & -16 & 0.001 \\
\hline Faecal dry wt & -18 & 9 & 0.0001 & 34 & 28 & $0 \cdot 35$ \\
\hline Faecal total SCFA & 15 & 40 & $0 \cdot 24$ & 60 & 35 & 0.27 \\
\hline \multicolumn{7}{|c|}{ Faecal SCFA: Total amount } \\
\hline Acetic & 14 & 40 & $0 \cdot 25$ & 60 & 32 & $0 \cdot 26$ \\
\hline Propionic & 19 & 85 & 0.02 & 56 & 72 & 0.53 \\
\hline Butyric & 21 & 34 & 0.62 & 72 & 53 & 0.60 \\
\hline \multicolumn{7}{|c|}{ Concentration } \\
\hline Acetic & 38 & 32 & $0 \cdot 79$ & 19 & 7 & $0 \cdot 48$ \\
\hline Propionic & 44 & 75 & $0 \cdot 25$ & 16 & 40 & $0 \cdot 26$ \\
\hline Butyrate & 47 & 27 & 0.55 & 28 & 23 & 0.89 \\
\hline Total SCFA & 40 & 33 & 0.72 & 19 & 9 & 0.54 \\
\hline
\end{tabular}

SCFA, short-chain fatty acids.

* For details of diet, see p. 742 and Table 1.

expected characteristics of $\mathbf{P}$ on caecal metabolism and stool output associated with a diet high in this fibre. However, fibre-reduced ( 6 weeks) $+P$ rats appeared less well adapted to the $P$ diet than the fibre-reduced (weaning) $+P$.

$P$ supplementation resulted in greater caecal sac weights in both groups of animals, although the fibre-reduced (weaning) $+\mathrm{P}$ rats had the largest caecum, probably due to a longer exposure to high levels of this soluble fibre. The fibre-reduced (weaning) + P rats had higher concentrations of total, acetate, propionate and butyrate, SCFA than the fibrereduced ( 6 weeks) + $P$ adults, and this may have influenced caecal sac proliferation (Sakata, 1987). These increases in caecal SCFA and the associated decrease in faecal weight in the fibre-reduced (weaning) $+P$ animals indicate a more efficient fermentation of $P$ and a somewhat different pattern of individual SCFA. This may be due simply to the longer exposure of the animals to the diet, but as the test period in both sets of animals was at least 4 weeks there should have been ample time to stimulate pectinolytic enzymes (Walter et al. 1986). It is also possible that exposure to high levels of $P$ at weaning may help establish a more specifically pectinolytic flora than that which can develop in a stable adult flora 
already adapted to a mixed-fibre diet. The differences between the fibre-reduced (weaning) + WB rats and the fibre-reduced $(6$ weeks) + WB rats were less pronounced both in terms of body-weight and caecal and faecal contents. This may be because the added WB is similar to the dietary fibre present in the CRMX diet so that differences are likely to be less marked. The increase in faecal output of both regimens supplemented with WB was similar. The mechanism of action of WB on stool output is not yet fully understood, but is thought to be related to its resistance to bacterial fermentation and water-holding capacity (Eastwood et al. 1983). Fibre-reduced (weaning) + WB also increased caecal total and butyrate SCFA compared with fibre-reduced (6 weeks) + WB. This may suggest a change in the fermentation of WB in the colons of the fibre-reduced ( 6 weeks) rats, perhaps by more specialized flora. On the other hand it is possible that increased fermentation and alterations in transit time may be important (Tomlin \& Read, 1988; Edwards et al. 1990).

The results of the present study have shown significant differences between caecal fermentation in animals weaned directly onto test diets and those initially weaned onto a standard rat diet. These differences may reflect a longer exposure ( $4 v .7$ weeks) to the test diet in those animals weaned onto the test diets, but may also indicate the establishment of a more specialized flora at weaning. Where rats have been weaned directly onto their test diet the adult colonic flora has developed from the sparse neonatal flora in the presence of, and perhaps in response to, the test complex carbohydrate. In contrast, the colonic flora of the rats exposed to the complex carbohydrates after preweaning on CRMX is already established and relatively stable. The flora in these animals has developed in response to the substrates in CRMX. Changing the bacterial spectrum or metabolism to one which has the fermentative capacity for a new carbohydrate similar to that of rats weaned directly onto it may not be possible or may take much longer.

$\mathrm{P}$ is better fermented in preweaned rats; therefore, more SCFA are produced in the caecum with less in the faeces. WB is not so affected, although there are some changes between weaned and adult fed rats. The previous feeding with the CRMX diet before a fibre-reduced diet results in higher residual caecal fermentation than in animals weaned onto a fibre-reduced diet.

In conclusion, these experiments indicate that early feeding at weaning in experimental animals has considerable influence on caecal metabolism, and in investigations where animals already weaned on to adult diets are subsequently placed on to experimental diets, results are only specific for that experimental design and cannot be applied universally. The diet previous to the experimental period must be taken into account when interpreting the findings obtained. These results may also indicate that the first solid food presented to infants after weaning may be important in influencing colonic metabolism and overall function.

The authors are grateful to Hans Englyst for the fibre analysis of the feeds and supplements.

\section{REFERENCES}

Chen, W. L. \& Anderson, J. W. (1984). Propionate may mediate the hypocholesterolaemic effects of plant fibers in cholesterol fed rats. Proceedings of the Society of Experimental Biology and Medicine 175, 215-218.

Demigne, C. \& Remesy, C. (1985). Stimulation of absorption of volatile fatty acids and minerals in the cecum of rats adapted to very high fiber diets. Journal of Nutrition 115, 53-60.

Eastwood, M. A., Kirkpatrick, R., Mitchell, W. D., Bone, A. \& Hamilton, T. (1973). Effects of dietary supplements of wheatbran and cellulose on faeces and bowel function. British Medical Journal 4, 392-394.

Eastwood, M. A., Robertson, J. A., Brydon, W. G. \& MacDonald, D. (1983). Measurement of water-holding properties of fibre and their faecal bulking ability in man, British Journal of Nutrition 50, 539-547.

Edwards, C. A., Bowen, J. \& Eastwood, M. A. (1990). The effect of isolated complex carbohydrates on caecal and faecal short chain fatty acids and stool weight in the rat. In Dietary Fibre: Chemical and Biological Aspects, pp. 
273-276 [D. A. T. Southgate, K. Waldron, I. T. Johnson and G. R. Fenwick, editors]. London: Royal Society of Chemistry.

Englyst, H., Wiggins, H. S. \& Cummings, J. H. (1982). Determination of the non-starch polysaccharides in plant foods by gas-liquid chromatography of constituent sugars as alditol acetates. Analyst 107, 307-318.

Illman, R. J., Trimble, R. P., Snoswell, A. M. \& Topping. D. L. (1982). Daily variations in the concentrations of volatile fatty acids in the splanchnic blood vessels of rats fed diets high in pectin and bran. Nutrition Reports International 26, 439-446.

McBurney, M. I., Hovarth, P. J., Jeraci, J. L. \& Van Soest, P. J. (1985). Effects of in vitro fermentation using human faecal innocula on the water holding capacity of dietary fibre. British Journal of Nutrition 53, 17-24.

Nyman, M. \& Asp, N.-G. (1985). Dietary fibre fermentation in the rat intestinal tract : effect of adaptation period, protein and fibre levels, and particle size. British Journal of Nutrition 54, 635-643.

Roediger, W. E. W. (1982). Utilisation of nutrients by isolated epithelial cells of the rat colon. Gastroenterolog; 83, 424-429.

Sakata, T. (1987). Stimulatory effect of short-chain fatty acids on epithelial cell proliferation in the rat intestine: a possible explanation for trophic effects of fermentable fibre, gut microbes and luminal trophic factors. British Journal of Nutrition 58, 95-103.

Savage, D. C. (1977). Microbial ecology of the gastrointestinal tract. Annual Review of Microbiology 31, 107-133.

Siljestrom, M. \& Asp, N.-G. (1985). Resistant starch formation during baking. Effect of baking time and temperature. Variation in the recipe. Zeitschrift für Lebensmittel Untersuchung und Forschung 181, 4-8.

Spiller, G. A., Chernoff, M. C., Hill, R. A., Gates, J. E., Nassar, J. J. \& Shipley, E. A. (1980). Effect of purified cellulose, pectin, and a low-residue diet on faecal volatile fatty acids, transit time and faecal weight in humans. American Journal of Clinical Nutrition 33, 754-759.

Tomlin, J. \& Read, N. W. (1988). The relationship between bacterial degradation of viscous polysaccharides and stool output in human beings. British Journal of Nutrition 60, 467-475.

Walter, D. J., Eastwood, M. A., Brydon, W. G. \& Elton, R. A. (1986). An experimental design to study colonic fibre fermentation in the rat: the duration of feeding. British Journal of Nutrition 55, $465-479$. 